\title{
IDENTIFIKASI MUTU FISIK, KIMIA DAN ORGANOLEPTIK ES KRIM DAGING KULIT MANGGIS (Garcinia mangostana L.) DENGAN VARIASI SUSU KRIM
}

\author{
IDENTIFICATION OF PHYSICAL, CHEMICAL AND ORGANOLEPTIC QUALITY \\ OF MANGOSTEEN LEATHER ICE CREAM \\ (Garcinia mangostana L.) WITH CREAM MILK VARIATION
}

\author{
Nopita Haryanti ${ }^{1)}$, Ahmad Zueni ${ }^{2)}$ \\ 1) Program Studi Teknologi Pertanian Fakultas Pertanian UNIVED \\ 2) Program Studi Teknologi Pangan Fakultas Pertanian UNIVED
}

\begin{abstract}
ABSTRAK
Manggis merupakan buah yang kandungan antioksidan tinggi terutama pada kulitnya. Daging kulit manggis mempunyai peluang untuk dikembangkan menjadi produk salah satunya adalah es krim. Es krim merupakan sejenis makanan semi padat dengan campuran susu, gula, cita rasa dan pengemulsi. Penelitian ini bertujuan untuk mengetahui mutu (fisik, kimia dan organoleptik) es krim daging kulit buah manggis.

Pembuatan es krim pada penelitian ini meliputi persiapan adonan, pencampuran, pengocokan, pemasakan, pengemasan, agitasi dan pembekuan. Variasi perlakuan pada penelitian ini adalah daging kulit manggis : susu krim $(100: 600,150: 550,200: 500,250$ : 450 dan 300 : 400) gram per mililiter. Rancangan penelitian yang digunakan adalah Rancangan Acak Lengkap (RAL) dengan lima perlakuan dan tiga ulangan, jika berbeda nyata dilanjutkan dengan uji DMRT. Analisa yang dilakukan yaitu overrun, kecepatan meleleh, kadar antioksidan dan organoleptik (warna, rasa dan tekstur).

Berdasarkan hasil analisis penelitian mutu fisik dan kimia yaitu pada perlakuan perbandingan daging kulit manggis 300 gram dan susu krim 400 mililiter. Sedangkan hasil analisis mutu organoleptik dari segi warna, rasa dan tekstur yang disukai panelis adalah pada perlakuan 200 gram daging kulit manggis dan 500 gram susu krim.
\end{abstract}

Kata Kunci : Daging Kulit Manggis, Susu Krim, Es Krim

\begin{abstract}
Mangosteen is a fruit that is high antioxidant content, especially on the skin. Meat mangosteen skin has a chance to develop into one product is ice cream. Ice cream is a kind of semi-solids with a mixture of milk, sugar, flavors and emulsifiers. This study aims to determine the quality (physical, chemical and organoleptic) ice cream mangosteen rind. Making ice cream in this study includes the preparation of the dough, mixing, shaking, cooking, packaging and freezing agitation. Variation of treatment in this study is mangosteen peel meat : milk cream (100:600, $150: 550,200: 500,250: 450$ and 300 : 400) grams per milliliter. The study design used was completely randomized design (CRD) with five treatments and three replications, if significantly different followed by DMRT. The analysis is done of the overrun, melting speed, the levels of antioxidants and organoleptic (color, flavor and texture).
\end{abstract}


Based on the analysis of physical and chemical quality of the research is on comparative treatment mangosteen peel 300 grams of meat and 400 milliliters of milk cream. While the results of the analysis of organoleptic quality in terms of color, taste and texture of the panelists preferred is the treatment of mangosteen peel 200 grams of meat and 500 grams of milk cream.

Keywords : Mangosteen Skin Meat, Milk Cream, Ice Cream

\section{PENDAHULUAN}

Manggis yang dalam bahasa latinnya dikenal dengan nama Garcinia mangostana L., merupakan tanaman buah berupa pohon yang berasal dari hutan tropis yang teduh di kawasan Asia Tenggara. Diantara semua negara yang tanahnya ditumbuhi pohon manggis, Indonesia termasuk sebagai salah satu produsen terbesar di dunia setelah Thailand. Direktorat Jenderal Hortikultura Departemen Pertanian Republik Indonesia mencatat, produksi manggis selama tahun 2005 mencapai 62.711 ton dari areal seluas 10.000 hektar. Sementara pada tahun yang sama, produksi manggis Thailand sudah mencapai 162.788 ton dari luas areal yang sama (Yusnilaningsih, 2009).

Buah manggis pada umumnya dikonsumsi daging buahnya sedangkan kulitnya yang mencakup tiga per empat bagian belum dimanfaatkan, padahal bagian yang paling berkhasiat bagi kesehatan tubuh adalah daging kulit buah manggis. Dalam daging kulit terdapat super antioksidan alami yang dikenal dengan nama xanthon, dimana antioksidan ini mampu menghambat pertumbuhan sel kanker dan mampu melindungi sel dari serangan radikal bebas penyebab berbagai gangguan penyakit, sehingga komoditas ini sangat dicari oleh kalangan farmasi untuk diekstrak dan dijadikan bahan baku obat herbal untuk penyakit kanker, darah tinggi, diabetes, prostat, penyakit paru, ginjal dan lain-lain (Carwadi, 2013).

Daging kulit manggis mempunyai peluang yang besar untuk dikembangkan menjadi sebuah produk karena memiliki berbagai manfaat untuk bahan makanan, pewarna alami dan untuk obat herbal. Tetapi pemanfaatan daging kulit manggis saat ini masih kurang sehingga perlu ditingkatkan. Daging kulit manggis dapat diolah menjadi berbagai produk olahan yang bervariasi atau lebih beragam demi meningkatkan nilai jual dan nilai gizi yang ada. Salah satu pemanfaatan daging kulit manggis adalah pengolahan daging kulit manggis menjadi es krim.

Es krim merupakan sejenis makanan semi padat yang dibuat dari campuran susu, lemak hewani atau nabati, gula dan dengan atau tanpa bahan makanan lain. 
Es krim merupakan salah satu makanan yang bernilai gizi tinggi. Nilai gizi es krim sangat tergantung pada nilai gizi bahan bakunya. Untuk membuat es krim yang bermutu tinggi, nilai gizi bahan bakunya perlu diketahui dengan pasti. Es krim merupakan produk pangan yang cocok dikonsumsi untuk iklim tropis, sehingga salah satu pilihan untuk menghilangkan dahaga. Es krim banyak digemari masyarakat diberbagai tingkatan usia, karena rasanya yang manis dan lumer dimulut. Salah satu faktor ang mempengaruhi kualitas es krim yaitu susu krim sebagai salah satu bahan dasarnya.

Susu krim mengandung $4 \%$ lemak dan mengandung vitamin $\mathrm{A}$ dan vitamin $\mathrm{D}$ (Muse and Hartel, 2004). Lemak bisa dikatakan sebagai bahan baku es krim, lemak yang terdapat pada es krim berasal dari susu segar yang disebut krim. Lemak susu berfungsi untuk meningkatkan nilai gizi es krim, menambah cita rasa, mencegah pembentukan kristal es, menghasilkan karakteristik tekstur yang lembut, membantu memberikan bentuk dan kepadatan serta memberikan sifat meleleh yang baik (Padaga et al., 2005).

Berdasarkan uraian tersebut maka peneliti ingin melakukan pengkajian tentang kulit manggis sebagai bahan fortivikasi dalam pembuatan es krim dengan variasi susu krim.

\section{METODE PENELITIAN}

\section{Bahan dan Alat}

Bahan-bahan yang digunakan dalam penelitian ini dibagi menjadi 2 macam yaitu bahan pembuatan es krim dan bahan-bahan kimia. Bahan-bahan dalam pembuatan es krim terdiri atas susu krim, susu cair, gula pasir, telur, vanilli, air dan kulit manggis. Sedangkan bahan-bahan kimia yang digunakan terdiri atas etanol, metanol, larutan DPPH (2,2-diphenil-1picrylhydrazil).

Alat-alat yang digunakan terdiri atas neraca analitik, kompor gas, blender, mixer, alat pengkukus, baskom dan pangaduk, refrigerator dan freezer, wadah es krim, gelas ukur, labu ukur, saringan dan stopwatch.

\section{Metode}

Penelitian ini dilakukan dengan perlakuan dua tahap yaitu yang pertama adalah pengolahan es krim dan tahap analisis.

Tahap pengolahan meliputi : tahap penyiapan bahan yaitu kulit manggis dicuci kemudian diambil daging kulit manggis $(100,150,200,250$ dan 300) gram dan dikukus selama 3 menit. Kemudian dihaluskan dengan perbandingan daging kulit manggis dan air yaitu 1:2 dan dilakukan penyaringan. Selanjutnya dilakukan dekantasi selama 7 jam kemudian diambil larutan bagian 
atas. Tahap pembuatan es krim aitu pencampuran bahan untuk adonan pertama; dimasukkan daging kulit manggis yang sudah disaring, susu krim (600, 550, 500, 450 dan 400) mililiter dan 125 mililiter susu cair, campuran dibuat sebanyak 5 perlakuan. Setelah bahan dari masing-masing perlakuan tercampur merata, campuran tersebut dipanaskan selama 30 menit lalu diangkat. Pencampuran bahan untuk adonan kedua; telur (kuning+putihnya) 4 butir, gula 100 gram, dan vanilli 6 gram, campuran tersebut dikocok (mixer), lalu dituangkan kedalam adonan pertama, kemudian dipanaskan (setelah mendidih) selama 25 detik dan diaduk hingga mengental. Setelah mengental adonan dituangkan ke dalam wadah es krim kemudian dilakukan proses aging dengan cara adonan disimpan dalam refrigerator pada suhu $4^{0} \mathrm{C}$ selama 3 - 4 jam. Pembekuan dan agitasi (pengadukan); adonan yang sudah diaging kemudian dipindahkan ke dalam freezer pada suhu $25^{0} \mathrm{C}$ sampai $-30^{0} \mathrm{C}$, setiap 1 jam diaduk supaya tidak terjadi pengkristalan es dan dapat dilakukan 3-4 kali.

Analisis yang dilakukan yaitu analisis fisik meliputi overrun dan kecepatan pelelehan. Sedangkan analisis kimianya meliputi analisis antioksidan. Serta analisis organoleptik meliputi parameter warna, rasa dan tekstur dengan menggunakan 20 panelis agak terlatih. Analisis data diolah menggunakan tabel anova dengan varian pada taraf signifikansi 5\%, jika perlakuan menunjukkan pengaruh yang nyata maka dilanjutkan dengan analisa Duncan Multiple Range Test (DMRT).

\section{HASIL DAN PEMBAHASAN}

\section{Overrun}

Overrun merupakan pengembangan volume yaitu kenaikan volume antara sebelum dan sesudah proses pembekuan. Overrun merupakan salah satu faktor yang mempengaruhi struktur es krim yang berhubungan dengan volume pengembangan es krim (Hubeis, 1995). Hasil analisis overrun es krim dengan perlakuan perbandingan konsentrasi daging kulit manggis dan susu krim dapat dilihat pada tabel 1 .

Dari tabel 1 diketahui bahwa hasil analisis overrun es krim dengan perlakuan perbandingan konsentrasi daging kulit manggis 300 gram dan susu krim 400 mililiter menghasilkan overrun yang paling tinggi yaitu 40,23\% sedangkan perlakuan perbandingan konsentrasi daging kulit manggis 100 gram dan susu krim 600 mililiter menghasilkan overrun es krim yang paling rendah $(30,89 \%)$. 
Tabel 1. Hasil Analisis Rata-rata Overrun Es Krim

\begin{tabular}{cc}
\hline Daging kulit manggis (gram) : susu krim (ml) & Overrun $(\%)$ \\
\hline $100: 600$ & $30,89 \mathrm{e}$ \\
$150: 550$ & $32,18 \mathrm{~d}$ \\
$200: 500$ & $35,70 \mathrm{c}$ \\
$250: 450$ & $37,45 \mathrm{~b}$ \\
$300: 400$ & $40,23 \mathrm{a}$
\end{tabular}

Keterangan : Angka yang diikuti oleh kode huruf yang berbeda menunjukkan adanya perbedaan yang nyata pada taraf signifikansi 5\%

Hal ini menunjukkan bahwa adanya pengembangan volume pada es krim karena adanya bahan pengemulsi (emulsifier) pada campuran es krim dan proses agitasi. Pantzaris (1995) menyatakan bahwa pemakaian emulsifier dimaksudkan untuk mengikat air agar berikatan dengan lemak sehingga membentuk es krim yang mempunyai daya mengembang yang bagus.

Hasil analisis varian pada taraf signifikansi $5 \%$ menyatakan bahwa masing-masing perlakuan didapat hasil yang berbeda nyata artinya es krim dengan perlakuan perbandingan konsentrasi daging kulit manggis dan susu krim berpengaruh sangat nyata terhadap overrun es krim yang dihasilkan pada masing-masing perlakuan.

Dari hasil penelitian juga terlihat bahwa semakin tinggi konsentrasi daging kulit manggis dan diikuti semakin rendah konsentrasi susu krim akan meningkatkan persentase overrun es krim dan sebaliknya semakin rendah konsentrasi daging kulit manggis dan diikuti semakin tinggi konsentrasi susu krim maka persentase overrun es krim semakin menurun. Persentase overrun es krim tinggi hal ini dikarenakan komposisi susu krim yang ditambahkan sedikit sehingga globula lemak dalam adonan juga sedikit sehingga dapat dengan mudah emulsifier memecah penggumpalan globula lemak dalam campuran es krim sehingga dapat mengembangkan adonan.

Hubeis (1995) menyatakan bahwa nilai overrun es krim dipengaruhi oleh faktorfaktor proses pembuatan dan komposisi es krim seperti kadar lemak. Berdasarkan pernyataan Potter dan Hotchkiss (1996) bahwa kuning telur merupakan emulsifier yang dapat pengembangan es krim, membantu memecah globula-globula lemak dalam campuran es krim dan mencegah penggumpalan globula lemak dan keluar dalam bentuk butiran mentega selama proses pencampuran sehingga dapat mencapai overrun yang diinginkan. 
Menurut Padaga et al., (2005) es krim yang berkualitas memiliki overrun berkisar antara $70-80 \%$ sedangkan untuk industri rumah tangga berkisar antara $35-50 \%$. Berdasarkan pernyataan tersebut, maka overrun perbandingan kosentrasi kulit manggis (200, 250 dan 300) gram dan susu krim (500, 550 dan 600) mililiter dengan overrun $(35,70 \%, 37,45 \%$ dan $40,23 \%)$ termasuk dalam golongan untuk industri rumah tangga.

\section{Kecepatan Meleleh}

Kecepatan meleleh adalah waktu yang dibutuhkan es krim untuk meleleh sempurna pada suhu ruang setelah pembekuan dalam freezer. Es krim diharapkan tidak cepat meleleh pada suhu ruang namun cepat meleleh pada suhu tubuh (Hubeis, 1995). Padaga et al., (2005) menyatakan bahwa lemak susu berfungsi untuk menghasilkan karakteristik tekstur yang lembut, membantu memberikan bentuk dan kepadatan serta memeberikan sifat meleleh yang baik. Hasil analisis kecepatan meleleh es krim dengan perlakuan perbandingan konsentrasi daging kulit manggis $(100,150,200,250$ dan 300) gram dan susu krim $(600,550$, 500, 450 dan 400) mililiter dapat dilihat pada tabel 2 .

Dari tabel 2 diketahui bahwa hasil analisis kecepatan meleleh es krim dengan perlakuan perbandingan konsentrasi daging kulit manggis 300 gram dan susu krim 400 mililiter menghasilkan kecepatan meleleh yang paling cepat yaitu 19 menit 10 detik sedangkan perlakuan perbandingan konsentrasi daging kulit manggis 100 gram dan susu krim 600 mililiter kecepatan meleleh es krim lebih lama yaitu 36 menit 13 detik. Hal ini menunjukkan bahwa konsentrasi susu krim yang ditambahkan akan mengurangi kecepatan meleleh pada es krim.

Tabel 2 Hasil Analisis Rata-rata Kecepatan Meleleh Es Krim

\begin{tabular}{cc}
\hline Daging kulit manggis (gram) : susu krim (ml) & Kecepatan meleleh (menit/10 gram) \\
\hline $100: 600$ & $36.13 \mathrm{a}$ \\
$150: 550$ & $32.28 \mathrm{~b}$ \\
$200: 500$ & $25.37 \mathrm{c}$ \\
$250: 450$ & $23.30 \mathrm{~d}$ \\
$300: 400$ & $19.10 \mathrm{e}$
\end{tabular}

Keterangan : Angka yang diikuti oleh kode huruf yang berbeda menunjukkan adanya perbedaan yang nyata pada taraf signifikansi 5\% 
Menurut Hyvonen et al., (2003) bahwa semakin tinggi kandungan lemak pada es krim maka akan semakin lama waktu pelelehan. Namun lemak yang terlalu banyak justru dapat mengakibatkan es krim menjadi keras.

Hasil analisis varian pada tarf signifikansi $5 \%$ menyatakan bahwa masing-masing perlakuan didapat hasil yang berbeda nyata. Artinya es krim dengan perlakuan perbandingan konsentrasi daging kulit manggis dan susu krim berpengaruh sangat nyata terhadap kecepatan meleleh es krim.

Dari tabel 2 juga terlihat bahwa semakin tinggi konsentrasi daging kulit manggis dan diikuti semakin rendah konsentrasi susu krim maka es krim akan cepat meleleh dan sebaliknya semakin rendah konsentrasi daging kulit manggis dan diikuti semakin tinggi konsentrasi susu krim maka semakin lama waktu yang dibutuhkan es krim untuk dapat meleleh dalam suhu ruang. Kecepatan meleleh yang lebih cepat hal ini dikarenakan konsentrasi susu krim paling sedikit yang artinya kadar lemak pada es krim lebih sedikit yang menyebabkan kepadatan es krim lebih rendah sehingga es krim lebih cepat meleleh. Hal ini sesuai dengan pernyataan Roland et al ., (1999), waktu leleh es krim akan semakin cepat pada es krim dengan kadar lemak rendah.
Kualitas meleleh yang baik pada es krim (10 gram) adalah 15 - 20 menit pada suhu ruang (Marshall dan Arbuckle, 1996). Berdasarkan pernyataan tersebut, maka kecepatan meleleh dengan perbandingan konsentrasi kulit manggis 300 gram dan susu krim 400 mililiter adalah es krim yang berkualitas bagus dengan kecepatan meleleh 19 menit 10 detik sedangkan es krim dengan perbandingan konsentrasi kulit manggis $(100,150,200$ dan 250) gram dan susu krim (600, 550, 500 dan 450) mililiter kurang berkualitas bagus.

\section{Sifat Kimia (Kadar Antioksidan) Es Krim}

Bahan pangan dan hasil pertanian mengandung senyawa kimia dengan komposisi kimia dan susunan tertentu menjadikan produk itu menjadi sifat khas, salah satunya antioksdan. Antioksidan adalah senyawa yang dapat menahan terjadinya reaksi oksidasi radikal bebas sehingga mampu melindungi tubuh dari kerusakan (Permana , 2010). Hasil analisis kadar antioksidan es krim dengan perlakuan perbandingan konsentrasi daging kulit manggis $(100,150,200,250$ dan 300) gram dan susu krim $(600,550,500,450$ dan 400) mililiter dapat dilihat pada tabel 3. 
Dari tabel 3 diketahui bahwa hasil analisis kadar antioksidan es krim dengan perlakuan perbandingan konsentrasi daging kulit manggis 300 gram dan susu krim 400 mililiter menghasilkan kadar antioksidan yang paling tinggi yaitu $63,79 \%$ sedangkan perlakuan perbandingan daging kulit manggis 100 gram dan susu krim 600 mililiter menghasilkan kadar antioksidan paling rendah yaitu 34,02 \%. Hal ini menunjukkan bahwa daging kulit manggis mempunyai kadar antioksidan yang tinggi. Iswari et al., (2005) menyatakan bahwa kandungan xanthon tertinggi terdapat dalam kulit buah yaitu mencapai 107,76 mg/100 gram kulit manggis. Xanthon adalah kandungan kimia yang terdapat dalam kulit manggis yang merupakan antioksidan alami yang mampu melindungi sel dari serangan radikal bebas penyebab berbagai penyakit.

Hasil analisis varian pada taraf signifikansi $5 \%$ menyatakan bahwa masing-masing perlakuan didapat hasil yang berbeda nyata. Artinya es krim dengan perlakuan perbandingan konsentrasi daging kulit manggis dan susu krim berpengaruh sangat nyata terhadap kadar antioksidan es krim pada masing-masing perlakuan.

Dari tabel 3 juga terlihat bahwa semakin tinggi konsentrasi daging kulit manggis dan diikuti semakin rendah konsentrasi susu krim maka semakin tinggi kadar antioksidan es krim dan sebaliknya semakin rendah konsentrasi daging kulit manggis dan diikuti semakin tinggi konsentrasi susu krim maka semakin rendah kadar antioksidan es krim. Persentase kadar antioksidan tinggi hal ini dikarenakan daging kulit manggis mempunyai kandungan kimia seperti xanthon, tanin dan antosianin yang merupakan antioksidan alami yang mampu melindungi sel dari serangan radikal bebas penyebab berbagai penyakit.
Tabel 3. Hasil Analisis Rata-rata Kadar Antioksidan Es Krim

Daging kulit manggis (gram) : susu krim (ml) Kadar antioksidan (\%)

$\begin{array}{ll}100: 600 & 34,02 \mathrm{e} \\ 150: 550 & 35,15 \mathrm{~d} \\ 200: 500 & 47,15 \mathrm{c} \\ 250: 450 & 54,32 \mathrm{~b} \\ 300: 400 & 63,79 \mathrm{a}\end{array}$

Keterangan : Angka yang diikuti oleh kode huruf yang berbeda menunjukkan adanya perbedaan yang nyata pada taraf signifikansi 5\% 
Kulit buah manggis kaya akan antioksidan terutama antosianin, xanthon, tanin dan asam fenolat yang berguna sebagai anti diabetes, anti kanker, anti peradangan, hepatoprotektif, meningkatkan kekebalan tubuh, anti bakteri, anti fungi, anti plasmodial dan aktivitas sitotoksik (Permana, 2010).

\section{Sifat Organoleptik Warna Es Krim}

Warna merupakan parameter organoleptik yang penting dalam suatu produk makanan. Warna merupakan parameter pertama yang menentukan tingkat penerimaan konsumen terhadap suatu produk. Warna menentukan penampilan makanan yang merupakan ransangan utama pada indera mata. Hasil analisis tingkat kesukaan panelis terhadap warna es krim dengan perlakuan perbandingan konsentrasi daging kulit manggis $(100,150,200,250$ dan 300) gram dan susu krim $(600,50,500,450$ dan 400) mililiter dapat dilihat pada tabel 4.

Dari tabel 4 diketahui bahwa hasil analisis organoleptik warna es krim dengan perlakuan perbandingan konsentrasi daging kulit manggis dan susu krim adalah berkisar antara 4,15 yang berarti suka sampai dengan 1,9 yang berarti sangat tidak suka. Hal ini menunjukkan bahwa susu krim dan daging kulit manggis dapat memberikan warna alami pada es krim sehingga dapat disukai oleh panelis.

Hasil analisis varian pada taraf signifikansi $5 \%$ menyatakan bahwa masing-masing perlakuan didapat hasil yang berbeda nyata. Artinya es krim dengan perlakuan perbandingan konsentrasi daging kulit manggis dan susu krim berpengaruh nyata terhadap warna es krim. Penilaian panelis terhadap warna es krim dengan perlakuan perbandingan konsentrasi daging kulit manggis 200 gram dan susu krim 500 mililiter tidak berbeda nyata dengan warna es krim pada perlakuan perbandingan konsentrasi daging kulit manggis 250 gram dan susu krim 450 mililiter. Warna es krim dengan perlakuan perbandingan konsentrasi daging kulit manggis dan susu krim (300 gram : 400 mililiter) dan (150 gram : 550 mililiter) tidak berbeda nyata dengan penilaian panelis yaitu 3,5 dan 3,4 yang berarti agak suka sedangkan perbandingan konsentrasi daging kulit manggis 100 gram dan susu krim 600 mililiter tidak disukai panelis. 
Tabel 4. Hasil Analisis Rata-rata Organoleptik Warna Es Krim

\begin{tabular}{cc}
\hline Daging kulit manggis (gram) : susu krim $(\mathrm{ml})$ & Organoleptik warna \\
\hline $100: 600$ & $1,9 \mathrm{c}$ \\
$150: 550$ & $3,4 \mathrm{~b}$ \\
$200: 500$ & $4,15 \mathrm{a}$ \\
$250: 450$ & $4,0 \mathrm{~b}$ \\
$300: 400$ & $3,5 \mathrm{~b}$
\end{tabular}

Keterangan : Angka yang diikuti oleh kode huruf yang berbeda menunjukkan adanya perbedaan yang nyata pada taraf signifikansi $5 \%$

Skala penilaian : 1 = sangat tidak suka, $2=$ tidak suka, $3=$ agak suka, $4=$ suka dan $5=$ sangat suka

Dari tabel 4 juga terlihat bahwa hasil analisis organoleptik warna es krim dengan perlakuan perbandingan konsentrasi daging kulit manggis 200 gram dan susu krim 500 mililiter adalah paling disukai panelis dengan penilaian 4,15 yang berarti suka sedangkan perlakuan perbandingan konsentrasi daging kulit manggis 100 gram dan susu krim 600 mililiter tidak disukai panelis dengan penilaian 1,9 yang berarti sangat tidak suka. Kesukaan panelis terhadap warna es krim dengan perbandingan kosentrasi daging kulit manggis 200 gram dan susu krim 500 mililiter $(4,15)$ karena warna es krim kuning alami sehingga menarik indra penglihatan. Berdasarkan pernyataan Astawan dan Andreas (2008) bahwa xanthon pada kulit manggis memberikan warna kuning. Pigmen alami ini akan mempengaruhi warna sari kulit buah manggis yang dihasilkan.

\section{Sifat Organoleptik Rasa Es Krim}

Rasa merupakan sensasi yang terbentuk dari hasil perpaduan bahan dan komposisinya pada suatu produk makanan oleh indra pengecap. Suatu produk dapat diterima oleh konsumen apabila memiliki rasa yang sesuai dengan yang diinginkan (Kartika, dkk, 1988). Hasil analisis tingkat kesukaan panelis terhadap rasa es krim dengan perlakuan perbandingan konsentrasi daging kulit manggis $(100,150,200,250$ dan 300) gram dan susu krim $(600,550,500,450$ dan 400) mililiter dapat dilihat pada tabel 5 .

Dari tabel 5 diketahui bahwa hasil analisis organoleptik rasa es krim dengan perlakuan perbandingan konsentrasi daging kulit manggis dan susu krim berkisar antara 2,2 yang berarti tidak suka sampai 4,15 yang berarti suka. Hal ini menunjukkan bahwa daging kulit manggis dapat memberikan rasa alami 
pada es krim sehingga dapat disukai oleh panelis.

Hasil analisis varian pada taraf signifikansi $5 \%$ menyatakan bahwa setiap perlakuan didapat hasil yang berbeda nyata. Artinya es krim dengan perlakuan perbandingan konsentrasi daging kulit manggis dan susu krim berpengaruh nyata terhadap rasa es krim. Penilaian panelis terhadap rasa es krim dengan perlakuan perbandingan konsentrasi daging kulit manggis dan susu krim (100 gram : 600 mililiter), (150 gram : 550 mililiter) dan (300 gram : 400 mililiter) tidak berbeda nyata.

Dari tabel 5 juga terlihat bahwa es krim dengan perlakuan perbandingan konsentrasi daging kulit manggis 200 gram dan susu krim 500 mililiter adalah rasa yang paling disukai panelis $(4,15)$ yang berarti suka sedangkan perlakuan perbandingan konsentrasi daging kulit manggis 100 gram dan susu krim 600 mililiter adalah rasa yang tidak disukai panelis dengan penilaian 2,2 yang berarti tidak suka. Kesukaan panelis terhadap rasa es krim dengan perbandingan konsentrasi daging kulit manggis 200 gram dan susu krim 500 mililiter $(4,15)$ hal ini dikarenakan adanya rasa manis dari susu cair dan gula, gurih dari susu krim dan tidak terlalu pahit dan sepat.

Daging kulit manggis dalam pembuatan es krim dengan berbagai konsentrasi akan mengubah rasa es krim yang dihasilkan yang mana dengan semakin banyaknya konsentrasi daging kulit manggis akan semakin meningkatkan rasa pahit dan sepet khas kulit manggis. Rasa pahit dan sepet berasal dari kandungan tanin yang terdapat dalam daging buah kulit manggis (Winarno, 2002).

Tabel 5. Hasil Analisis Rata-rata Organoleptik Rasa Es Krim

\begin{tabular}{cc}
\hline Daging kulit manggis (gram) : susu krim (ml) & Organoleptik rasa \\
\hline $100: 600$ & $2,2 \mathrm{c}$ \\
$150: 550$ & $2,8 \mathrm{~b}$ \\
$200: 500$ & $4,15 \mathrm{a}$ \\
$250: 450$ & $3,6 \mathrm{a}$ \\
$300: 400$ & $2,6 \mathrm{bc}$
\end{tabular}

Keterangan : Angka yang diikuti oleh kode huruf yang berbeda menunjukkan adanya perbedaan yang nyata pada taraf signifikansi $5 \%$

Skala penilaian : $1=$ sangat tidak suka, $2=$ tidak suka, $3=$ agak suka, $4=$ suka dan $5=$ sangat suka 
Sifat Organoleptik Tekstur Es Krim

Tekstur merupakan salah satu faktor sensoris yang berkaitan dengan tingkat kekerasan dan kelembutan suatu produk. Untuk merasakan tekstur produk makanan digunakan indera peraba salah satuna mulut yaittu dengan menggunakan lidah dan bagian-bagian di dalam mulut, dapat juga dengan menggunakan tangan sehingga dapat merasakan tekstur suatu produk makanan. Tekstur juga menjadi salah satu faktor penentu kualitas yang perlu diperhatikan (Kartika, dkk, 1988). Hasil analisis tingkat kesukaan panelis terhadap tekstur es krim dengan perlakuan perbandingan konsentrasi daging kulit manggis $(100,150,200,250$ dan 300) gram dan susu krim $(600,550$, 500, 450 dan 400) mililiter dapat dilihat pada tabel 6 .

Dari tabel 6 diketahui bahwa hasil analisis organoleptik tekstur es krim dengan perlakuan perbandingan konsentrasi daging kulit manggis dan susu krim adalah berkisar antara 2,0 yang berarti tidak suka sampai 4,3 yang berarti suka. Hal ini menunjukkan bahwa susu krim dapat memberikan tekstur yang baik pada es krim sehingga dapat disukai oleh panelis.

Hasil analisis varian pada taraf signifikansi $5 \%$ menyatakan bahwa masing-masing perlakuan didapat hasil yang berbeda nyata. Artinya es krim dengan perlakuan perbandingan konsentrasi daging kulit manggis dan susu krim berpengaruh nyata terhadap tekstur es krim. Penilaian panelis terhadap tekstur es krim dengan perlakuan perbandingan konsentrasi daging kulit manggis dan susu krim (100 gram : 600 mililiter) dan (150 gram : 550 mililiter) tidak berbeda nyata dengan nilai 2,0 dan 2,4 yang berarti tidak suka sedangkan tekstur es krim dengan perlakuan perbandingan konsentrasi daging kulit manggis dan susu krim (300 gram : 400 mililiter) dan (250 gram : 450 mililiter) tidak berbeda nyata dengan penilaian 3,4 dan 3,8 yang berarti agak suka.

Dari tabel 6 juga terlihat bahwa es krim dengan perlakuan perbandingan konsentrasi daging kulit manggis 200 gram dan susu krim 500 mililiter adalah tekstur yang paling disukai panelis dengan skala penilaian 4,3 yang berarti suka sedangkan perlakuan perbandingan konsentrasi daging kulit manggis 100 gram dan susu krim 600 mililiter adalah tekstur yang tidak disukai panelis dengan penilaian 2,0 yang berarti tidak suka. Tekstur es krim dengan perlakuan perbandingan konsentrasi daging kulit manggis 200 gram dan susu krim 500 mililiter dengan penilaian $(4,15)$ disukai panelis hal ini dikarenakan teksturnya lembut dan tidak keras 
Tabel 6. Hasil Analisis Rata-rata Organoleptik Tekstur Es Krim

\begin{tabular}{cc}
\hline Daging kulit manggis (gram) : susu krim (ml) & Organoleptik tekstur \\
\hline $100: 600$ & $2,0 \mathrm{c}$ \\
$150: 550$ & $2,4 \mathrm{c}$ \\
$200: 500$ & $4,3 \mathrm{a}$ \\
$250: 450$ & $3,8 \mathrm{ab}$ \\
$300: 400$ & $3,6 \mathrm{~b}$
\end{tabular}

Keterangan : Angka yang diikuti oleh kode huruf yang berbeda menunjukkan adanya perbedaan yang nyata pada taraf signifikansi $5 \%$

Skala penilaian : $1=$ sangat tidak suka, $2=$ tidak suka, $3=$ agak suka, $4=$ suka dan $5=$ sangat suka

Overrun akan mempengaruhi tekstur dan kepadatan yang sangat menentukan kualitas es krim (Padaga et al., 2005). Overrun yang rendah akan menghasilkan tekstur es krim yang keras dan padat sedangkan overrun yang tinggi akan menghasilkan tekstur es krim yang lembut dan mudah mencair sehingga panelis menyukai tekstur es krim dengan perlakuan perbandingan konsentrasi daging kulit manggis 200 gram dan susu krim 500 mililiter dengan nilai overrun $35,70 \%$ dengan tekstur tidak terlalu padat dan tidak terlalu lembut.

Padaga et al., (2005) menyatakan bahwa tekstur es krim yang baik adalah halus dan lembut (smooth), tidak keras dan tampak mengkilat sedangkan yang buruk adalah adanya rasa gumpalan lemak (greasy), terasa seperti tepung (grainy), terasa adanya serpihan es (flak atau snowy) dan berpasir (sandy). Tekstur dipengaruhi oleh beberapa faktor yaitu komposisi es krim mix, cara pengolahan, kondisi penyimpanan, kristal es, globula lemak, gelembung udara dan kristal laktosa. Pengembangan volume adonan es krim menjadikan es krim lebih ringan dan tidak terlalu padat serta mempunyai tekstur yang lembut.

\section{SIMPULAN}

Mutu fisik es krim yang dihasilkan adalah pada perlakuan perbandingan konsentrasi daging kulit manggis 300 gram dan susu krim 400 mililiter dengan nilai overrun yaitu $40,23 \%$ dan kecepatan meleleh adalah 19 menit 10 detik. Mutu kimia (kadar antioksidan) es krim yang dihasilkan adalah pada perlakuan perbandingan konsentrasi daging kulit manggis 300 gram dan susu krim 400 mililiter dengan nilai 63,79\%. Mutu organoleptik es krim yang 
dihasilkan adalah pada perlakuan perbandingan konsentrasi daging kulit manggis 200 gram dan susu krim 500 mililiter dengan penilaian warna 4,15 , rasa 4,51 dan tekstur 4,3 yang berarti suka. Es krim yang dihasilkan pada penelitian ini adalah es krim yang mempunyai kandungan antioksidan yang tinggi $(63,79 \%)$ sehingga memiliki fungsi lain yakni sebagai pangan fungsional.

\section{DAFTAR PUSTAKA}

Astawan M., dan Andreas L. K., 2008, Khasiat Warna-warni Makanan. Gramedia. Jakarta.

Carwadi Dadi., 2013, Manfaat Kulit Manggis Untuk Kesehatan, http://manfaatdaunbuah.blogspot. com/2013/09/manfaat-kulitmanggis-untuk-kesehatan.html, diakses tanggal 15 September 2014.

Hyvonen L., M. Linna, H. Tourila dan G. Dijksterhuis. 2003. Perciption of Melting and Flovor Release of Ice Cream Containing Different Types and Contents of Fat, Jornal of Dairy Science Vol. 86, No 4, page 1130-1138.

Hubeis M., 1995, Paket Industri Pangan Es Krim Ekonomi Skala Industri Kecil, Bulletin Fakultas Teknologi Industri Pangan, Institut Pertanian Bogor, Vol. VII (I), Hal 100-102.

Iswari K., E. Afdi, dan Harnel, 2005, Pengkajian Profil Usahatani dan
Pemasaran Buah Manggis di Sumbar, Laporan Hasil Penelitian BPTP Sumatra Barat.

Kartika, B., Hastuti, P dan Supartono, W. 1988. Pedoman Uji Inderawi Bahan Pangan. PAU Pangan dan Gizi-UGM, Yogyakarta.

Marshall R.T. and W.S. Arbuckle, 1996, Ice Cream, $5^{\text {th }}$ Edition, Internatioan Thompson Publishing, New York.

Muse M.R. and Hartel, R.W., 2004, Ice Cream Structural Elements That Affect Melting Rate and Hardness American Dairy Science Association. Jurnal of dairy science $87: 1-10$.

Padaga M dan Manik E. Sawitri, 2005, Es Krim Yang Sehat, Trubus Agrisarana, Surabaya.

Petter N.N. dan J.H.Hotckiss, 1996, Food Science ${ }^{5 t h}$ Edition. CBS Publisher dan Distributors. New Delhi.

Pantzaris, 1995, Principle of Barley Chemistry, Wiley Eastern Private Ltd, New Delhi.

Permana A.W., 2010, Kulit Buah Manggis dapat Menjadi Minuman Instan Kaya Antioksidan, Warta Litbang Deptan 32(2): 3 hal.

Roland, A. M., L. G. Phillips and K. J. Boor, 1999, Effects of fat content on the sensory properties, melting, colour and hardness of ice cream. J. Dairy Sci. 82: 32 38.

Winarno, 2002, Kimia Pangan dan Gizi, Gramedia, Jakarta.

Yusnilaningsih R., 2009, Pewarna Alami dari Buah Manggis, http://newspaper.pikiranrakyat.com, diakses 21 November 2013. 